\title{
Copper-67 as a therapeutic nuclide for radioimmunotherapy
}

\author{
Ilse Novak-Hofer, P. August Schubiger \\ Center for Radiopharmaceutical Science ETH-PSI-USZ, Paul Scherrer Institute, CH-5232 Villigen, Switzerland \\ Published online: 2 February 2002 \\ (C) Springer-Verlag 2002
}

\begin{abstract}
The application of the beta particle-emitting nuclide ${ }^{67} \mathrm{Cu}$ in radioimmunotherapy is reviewed. The production of the nuclide is outlined, and different production modes are discussed with an emphasis on cyclotron production. A short survey of copper chelators currently used for antibody labelling and their impact on the pharmacokinetics of ${ }^{67} \mathrm{Cu}$-labelled immunoconjugates is provided. Protocols for antibody labelling with ${ }^{67} \mathrm{Cu}$ as well as quality control procedures for ${ }^{67} \mathrm{Cu}$-labelled antibodies are described. Preclinical data on the biological properties of ${ }^{67} \mathrm{Cu}$-labelled immunoconjugates are reported and discussed. ${ }^{67} \mathrm{Cu}$-labelled antibodies show higher and more persistent tumour uptake than their radioiodinated counterparts due to accumulation of labelled metabolites in tumour cells. Biodistribution of ${ }^{67} \mathrm{Cu}$-labelled antibody fragments has been improved by selection of negatively charged chelators and peptide linkers. Pharmacokinetic analysis of the accumulated dose in tumour and critical organs such as the kidney and liver indicates that, despite this improvement, intact ${ }^{67} \mathrm{Cu}$-labelled antibodies achieve higher tumour uptake and better therapeutic ratios than ${ }^{67} \mathrm{Cu}$-labelled antibody fragments and that they are at present the logical choice for clinical studies. Clinical studies using ${ }^{67} \mathrm{Cu}$-labelled antibodies in lymphoma, colon carcinoma and bladder cancer patients are reviewed. Some of the advantages over radioiodinated antibodies found in the preclinical work, such as higher tumour uptake and better tumour/blood ratios, have also been found with systemic application in lymphoma and colon carcinoma. However, in both lymphoma and colon carcinoma patients, the radiation dose to the liver has been found to be higher from ${ }^{67} \mathrm{Cu}$ - than from ${ }^{131}$ I-labelled antibodies. The intravesical application of ${ }^{67} \mathrm{Cu}$-labelled antibody has been shown to be a promising approach for targetting cytotoxic radiation to superficial bladder tumours, without detectable systemic absorption. Given the favourable properties of ${ }^{67} \mathrm{Cu}$-labelled antibodies, it is the reliable avail-
\end{abstract}

\footnotetext{
P. August Schubiger (

Center for Radiopharmaceutical Science ETH-PSI-USZ,

Paul Scherrer Institute, CH-5232 Villigen, Switzerland

e-mail: august.schubiger@psi.ch

Tel.: +41-56-3102813, Fax: +41-56-3102849
}

ability of the ${ }^{67} \mathrm{Cu}$ nuclide which is the limiting factor for their more widespread evaluation in radioimmunotherapy trials.

Keywords: Radioimmunotherapy $-{ }^{67} \mathrm{Cu}-{ }^{67} \mathrm{Cu}$ production $-{ }^{67} \mathrm{Cu}$ chelates - Clinical studies

Abbreviations: CPTA: 4-(1,4,8,11-tetraazacyclotetradec1-yl)-methyl benzoic acid tetrachloride $\cdot$ DO3A: 1-(p-nitrobenzyl)-1,4,7,10-tetraazacyclodecane-4,7,10-triacetate . DOTA: 3-( $p$-nitrobenzyl)-1,4,7,10-tetraazacyclodecane1,4,7,10-tetraacetate FPLC: fast protein liquid chromatography - HAMA: human antimouse antibodies - TETA: 6-( $p$-nitrobenzyl)-1,4,8,11-tetraazacyclotetradecane-

1,4,8,11-tetraacetic acid

Eur J Nucl Med (2002) 29:821-830

DOI 10.1007/s00259-001-0724-y

\section{Introduction}

Monoclonal antibodies have been recognised as highly selective agents for systemic nuclide therapy for a long time. Due to the persistent efforts to improve their efficacy, a clinical impact of radioimmunotherapy (RAIT) is already apparent in the treatment of haematological malignancies. Especially in non-Hodgkin's lymphoma, notable clinical responses have been observed in patients with relapsed, chemotherapy-resistant disease and various radiolabelled antibodies are in phase I/II/III trials (as reflected, for instance, in the increasing number of abstracts on the subject at the EANM annual meetings). In the management of solid tumours, RAIT may be more effective in the treatment of residual disease and/or adjuvant settings, and especially locoregional applications of radiolabelled antibodies appear to be a favourable modality. ${ }^{131} \mathrm{I}$ and ${ }^{90} \mathrm{Y}$ are now the most widely used beta particle-emitting nuclides in clinical RAIT. The high energy of ${ }^{90} \mathrm{Y}$ and its long particle range make it suitable for irradiating large tumour masses. For the treatment of small, distant metastases, a variety of beta particle-emitting nuclides covering a range of energies and thus pene- 
Table 1. Physical properties and more frequently used production modes for ${ }^{67} \mathrm{Cu} /{ }^{64} \mathrm{Cu}$

\begin{tabular}{lllrrl}
\hline Nuclide & $T_{1 / 2}(\mathrm{~h})$ & Decay mode & $\mathrm{E}_{\beta}(\mathrm{keV}, \%)$ & $\mathrm{E}_{\gamma}(\mathrm{keV}, \%)$ & Production mode \\
\hline${ }^{67} \mathrm{Cu}$ & 61.9 & $\beta^{-}(100 \%)$ & $395(51 \%)$ & $91(6 \%)$ & Cyclotron natZn (p, 2p) \\
& & & $484(28 \%)$ & $93(35 \%)$ & Cyclotron ${ }^{8} \mathrm{Zn}(\mathrm{p}, 2 \mathrm{p})$ \\
& & $577(20 \%)$ & $185(45 \%)$ & Reactor natZn (n, p) \\
& & & $300(0.6 \%)$ & \\
${ }^{64} \mathrm{Cu}$ & 12.7 & $\beta^{-}(39.6 \%)$ & $573(40 \%)$ & $511(39 \%)$ & Reactor \\
& & $\mathrm{EC}(45.0 \%)$ & & $1,346(0.6 \%)$ & Cyclotron \\
& & & & \\
\hline
\end{tabular}

tration ranges would be of interest, because then the penetration range of the nuclide could be matched to the tumour size [1,2]. Also a choice amongst nuclides with different half-lives would be useful, to permit matching of the physical half-life of the nuclide to the different pharmacokinetics of intact antibodies and antibody fragments. Apart from the physical properties of the nuclide, its availability and the existence of simple and efficient radiolabelling methods are important considerations. On the biological side, the fate of the nuclide after antibody metabolism in vivo plays an important role and is also dependent on the nuclide used and the labelling chemistry involved.

The physical properties of the ${ }^{67} \mathrm{Cu}$ nuclide are very well suited for its application in RAIT and are summarised in Table $1 .{ }^{67} \mathrm{Cu}$ is a beta particle-emitting nuclide with $\beta^{-}$emissions distributed between 577 and $395 \mathrm{keV}$, resulting in a mean energy of $141 \mathrm{keV}$, similar to the mean $\beta$ energy of ${ }^{131} \mathrm{I}(180 \mathrm{keV})$. These therapeutic $\beta^{-}$ emissions, with a mean range of $0.2 \mathrm{~mm}$, are very appropriate for the treatment of small tumours up to $5 \mathrm{~mm}$ in diameter. ${ }^{67} \mathrm{Cu}$ also emits $\gamma$-radiation in the range 91-184 keV (49\% abundance), an energy range which is particularly suitable for pretherapy diagnostic imaging with a gamma camera. In contrast to the high level (>90\%) of penetrating $\gamma$-radiation associated with the ${ }^{131}$ I nuclide, which adds to the whole-body dose of the patient and to the radiation burden of the hospital staff, the lower abundance and energy of the $\gamma$ emissions from ${ }^{67} \mathrm{Cu}$ represent a distinct advantage. Given the relatively slow pharmacokinetics of intact antibody molecules, the half-life of the ${ }^{67} \mathrm{Cu}$ nuclide of 2.58 days is long enough to permit accumulation of antibody at the tumour site. On the other hand, its half-life is not as long as that of ${ }^{131} \mathrm{I}\left(T_{1 / 2}=8.04\right.$ days $)$, and ${ }^{67} \mathrm{Cu}$ thus provides a higher dose rate to the tumour.

This review will cover preclinical and clinical studies performed with ${ }^{67} \mathrm{Cu}$-labelled antibodies, which all indicate the great potential of ${ }^{67} \mathrm{Cu}$ for RAIT. Results obtained so far indicate that a commitment to producing this interesting nuclide for clinical studies is a worthwhile endeavour. ${ }^{64} \mathrm{Cu}$, a positron-emitting nuclide used for positron emission tomography (PET) imaging will not be treated comprehensively in this review, but studies with ${ }^{64} \mathrm{Cu}$-labelled antibody or peptide conjugates will be mentioned in some instances, when pertinent to nuclide therapy using the ${ }^{67} \mathrm{Cu}$ sister nuclide.

\section{Production of ${ }^{67} \mathrm{Cu}$}

As indicated in Table $1,{ }^{67} \mathrm{Cu}$ can be produced by bombarding ${ }^{67} \mathrm{Zn}$ with neutrons in high flux reactors [3], or with cyclotrons by irradiating natZn or enriched ${ }^{68} \mathrm{Zn}$ with protons $[4,5]$. These are the most commonly used procedures; other less practicable methods such as irradiation by $\alpha$-particles are listed in, for instance [4]. As reactors are getting to be rare (at least in Europe), production routes from cyclotrons are of particular interest. In the case of ${ }^{67} \mathrm{Cu}$ production using cyclotrons, the yield from the (p, 2p) nuclear reactions is relatively low, and efficient separation procedures to remove the contaminating nuclides have had to be developed [4]. The main contaminants are ${ }^{62} \mathrm{Zn},{ }^{67} \mathrm{Ga},{ }^{65} \mathrm{Zn},{ }^{55} \mathrm{Co},{ }^{58} \mathrm{Co}$ and ${ }^{57} \mathrm{Ni}$, all of which can be removed by sequential steps of ion exchange chromatography. ${ }^{67} \mathrm{Cu}$ produced via this no-carrier-added production is, however, not carrier free, owing to the difficulty of removing trace contaminants of $\mathrm{Cu}$ in the $\mathrm{Zn}$ target, apparatus and solutions. Current ${ }^{67} \mathrm{Cu}$ productions have a specific activity of about 37-185 MBq/ug [4, 5] and as a consequence less than $1 \%$ of the copper atoms are radioactive. Because the yield of the nuclear ( $p, 2 p)$ reaction for ${ }^{64} \mathrm{Cu}$ is higher than for ${ }^{67} \mathrm{Cu},{ }^{64} \mathrm{Cu}$ is produced simultaneously with ${ }^{67} \mathrm{Cu}$ and remains present in ${ }^{67} \mathrm{Cu}$ preparations for several days, despite its shorter half-life $\left(T_{1 / 2}=12.7 \mathrm{~h}\right)$.

${ }^{67} \mathrm{Cu}$ has been produced in the United States with high-energy accelerators at Brookhaven and Los Alamos National Laboratories but is not provided on a routine basis by these institutions. Since 1994, the Center for Radiopharmaceutical Science at the Paul Scherrer Institute (PSI) in Switzerland has produced ${ }^{67} \mathrm{Cu}$ for its own use with a $72-\mathrm{MeV}$ accelerator. An increase in ${ }^{67} \mathrm{Cu}$ production at PSI from the present $3.7 \mathrm{GBq}$ to a projected $17 \mathrm{GBq}$ is currently being affected by use of enriched ${ }^{68} \mathrm{Zn}$ as the target material. Figure 1 shows the yield of ${ }^{67} \mathrm{Cu}$ using nat $\mathrm{Zn},{ }^{68} \mathrm{Zn}$ and ${ }^{70} \mathrm{Zn}$ targets and a proton beam with energies up to $70 \mathrm{MeV}$. Results indicate that using ${ }^{68} \mathrm{Zn}$ targets instead of nat $\mathrm{Zn}$ leads to a 4.5 -fold increase in ${ }^{67} \mathrm{Cu}$ production in the energy range between 


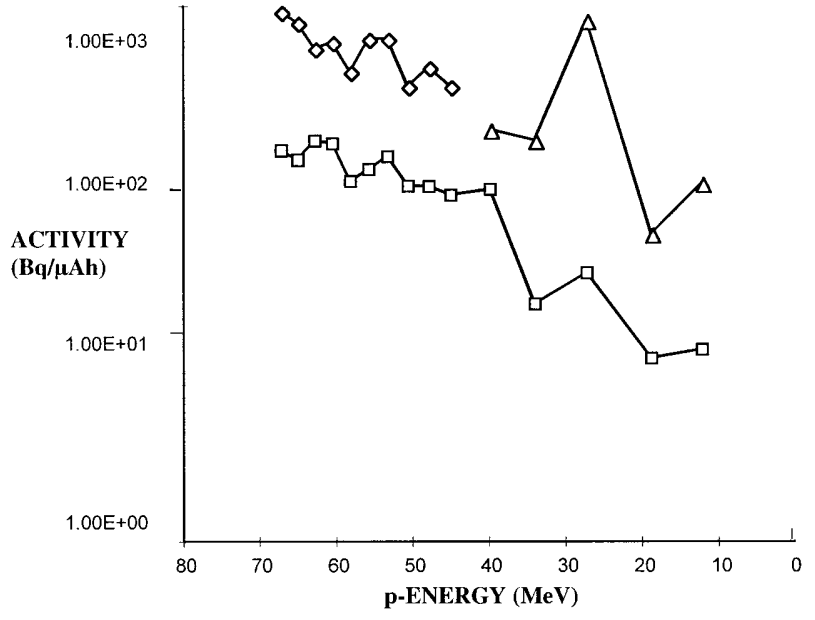

Fig. 1. Yields (on a log scale) of ${ }^{67} \mathrm{Cu}$ activity produced by proton irradiation of $\mathrm{Zn}$ targets. Compared with the irradiation of natural $\mathrm{Zn}$ targets (squares), use of enriched ${ }^{68} \mathrm{Zn}$ (diamonds) gives a 4.5 fold increase in ${ }^{67} \mathrm{Cu}$ in the energy range between 45 and $67 \mathrm{MeV}$ and the use of enriched ${ }^{70} \mathrm{Zn}$ (triangles) gives a 10 - to 20 -fold increase in ${ }^{67} \mathrm{Cu}$ in the low energy range between 20 and $30 \mathrm{MeV}$. (From Schwarzbach et al. [6])

40 and $70 \mathrm{MeV}$. In a narrow low-energy range between 20 and $30 \mathrm{MeV}$, irradiation of a ${ }^{70} \mathrm{Zn}$ target would increase yields of ${ }^{67} \mathrm{Cu} 10$ - to 20 -fold. The high cost of the ${ }^{70} \mathrm{Zn}$ target makes its use impractical, however. Using a ${ }^{68} \mathrm{Zn}$ target, which can be recycled, will allow the production of about $17 \mathrm{GBq}$ of ${ }^{67} \mathrm{Cu}$, which is sufficient for achieving several therapeutic doses of antibody, envisaging $2.2 \mathrm{GBq}(60 \mathrm{mCi})$ as the highest dose level [6].

When higher energy proton beams and higher beam currents are available, about 10 times more ${ }^{67} \mathrm{Cu}$ will be produced per mass unit of $\mathrm{Zn}$. Thus, sufficient amounts of ${ }^{67} \mathrm{Cu}$ for RAIT trials can be produced by cyclotrons, if either enriched $\mathrm{Zn}$ targets are used or a high-energy proton beam is available.

\section{Copper chelates and ${ }^{67} \mathrm{Cu}$ labelling of antibodies}

One of the advantages of the copper nuclides compared with other radiometals of interest for nuclide therapy consists in the availability of excellent chelating agents (Fig. 2). The prototype is the macrocyclic chelator 1,4,8,11-tetraazacyclotetradecane- $N, N^{\prime}, N^{\prime \prime}, N^{\prime \prime}$-tetraacetic acid (TETA, Fig. 2A) developed for copper labelling by the Meares group [7, 8] a bifunctional carboxylated cyclam-14 derivative which complexes copper selectively and rapidly at ambient temperature $[9,10]$. This property permits convenient postconjugation labelling protocols at temperatures maintaining protein function.

The pharmacokinetics of antibodies are characterised by long biological half-lives in the blood and in the tumour, and the copper nuclide has to remain stably encap-
A

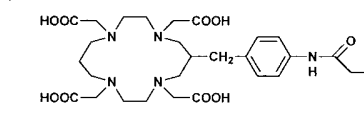

BAT

B

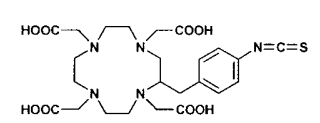

NCS-DOTA

C

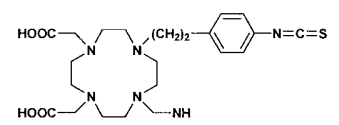

NCS-DO3A

D

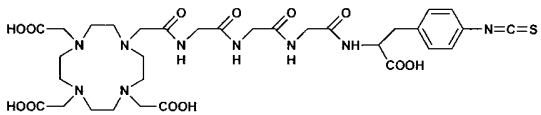

NCS-R1-DOTA

E

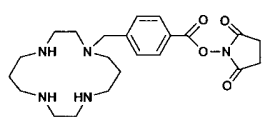

NHS-CPTA

F

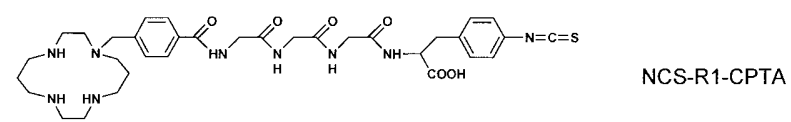

Fig. 2A-F. Structures of selected macrocyclic bifunctional chelators used for ${ }^{67} \mathrm{Cu}$ labelling of antibodies. A 6-[ $p$-(bromoacetamido)benzyl]-TETA (BAT); B 3-(L-p-isocyanato-phenylalanine)DOTA (NCS-DOTA); C 1-(L-p-isocyanato-phenylalanine)-DO3A (NCS-DO3A); D DOTA-triglycyl-L- $p$-isocyanato-phenylalanine (NCS-R1-DOTA; E 1-(p-phenyl- $N$-hydroxysuccinimide)-CPTA (NHS-CPTA); $\quad$ F CPTA-triglycyl-L- $p$-isocyanato-phenylalanine (NCS-R1-CPTA)

sulated in the chelator. Kinetic inertness of copper complexes is the determining factor for release of radiocopper from antibody conjugates. The TETA ligand, as well as a number of other $4 \mathrm{~N}$ macrocycles $[11,12,13]$ depicted in Fig. 2, forms copper (II) complexes of high thermodynamic stability, which also exhibit high kinetic stability under physiological conditions [10]; this is one of the reasons for the excellent tumour targetting ability of ${ }^{67} \mathrm{Cu}$-labelled antibodies. Positioning of the side chain on the TETA macrocycle influences the kinetic stability of the copper complex, with the 6-position of the side chain providing higher stability in human serum than the macrocycle with the side chain at the 2-position [10]. There are different possibilities to attach the linkage group to the DOTA chelate: on the macrocycle via a $\mathrm{C}-\mathrm{C}$ bond (Fig. 2B) or on the acetate chelating arm via a $\mathrm{C}-\mathrm{N}$ bond ("DO3A") (Fig. 2C). Both ligands form very stable copper complexes but the DO3A ligand has been used more, possibly because of the more convenient synthesis $[12,14]$. Intact antibodies are metabolised in the liver where copper binding proteins such as ceruloplasmin and superoxide dismutase are present in high concentrations. Despite the high kinetic stability of the TETA copper complex, transchelation of $\mathrm{Cu}$ from 
the complex to these proteins in the liver has been observed in vivo with ${ }^{67} \mathrm{Cu}$-TETA-labelled antibodies and ${ }^{64} \mathrm{Cu}$-TETA-labelled octreotide $[15,16]$. We have also observed that ${ }^{67} \mathrm{Cu}-\mathrm{DO} 3 \mathrm{~A}-$-labelled antibodies and antibody fragments are characterised by relatively high levels of activity in the liver. Ongoing interest therefore exists in designing copper chelates of even higher in vivo stability. Recently, cross-bridged cyclam ligands were synthesised with increased reduction potential in order to lessen the electrochemical reduction of $\mathrm{Cu}$ (II) to $\mathrm{Cu}(\mathrm{I})$, which is believed to affect dissociation of copper from the complex $[17,18]$. However, complexation of copper with these ligands requires elevated temperatures $\left(75^{\circ} \mathrm{C}\right)$, which is not optimal for postconjugation labelling of proteins, and these ligands therefore may be more suitable for peptide labelling. The neutral tetra-aza macrocycle CPTA (Fig. 2E) exhibits a particularly high stability towards acid-promoted dissociation of copper from the complex [12,19], which is relevant in the acidic environment of lysosomes in antibody-metabolising tissues such as the liver.

Besides the in vivo stability of the used copper complexes, their charge and lipophilicity also have an important impact on the biodistribution of ${ }^{67} \mathrm{Cu}$-labelled immunoconjugates. Macrocyclic copper complexes bearing different charges and exhibiting different degrees of lipophilicity, such as ${ }^{67} \mathrm{Cu}-\mathrm{CPTA}$, -TETA or -DO3A complexes, lead to distinct differences in biodistribution when used for labelling of antibody fragments. The chelates (TETA, DOTA, DO3A) with carboxylic groups (pKa values in the range 2-5) attached to the nitrogen donor atoms are very hydrophilic. Indeed, clearance of radioactivity from the kidneys was found to be much faster in the case of antibody fragments substituted with negatively charged hydrophilic copper complexes [20, 21].

Bifunctional copper chelators contain, in addition to the metal chelating unit, a linkage and conjugation group for attachment to the tumour-seeking moiety. Conjugation of chelates to antibodies is performed via electrophilic conjugation groups (activated esters), attached to a linker, which can be a phenyl group or a short peptide in addition to the phenyl group. Figure 2 shows the most frequently used conjugation groups: bromoacetamide (BA) attached to the TETA ligand (BAT, Fig. 2A), isothiocyanate (NCS) attached to DOTA or DO3A ligands (Fig. 2B, C, D) and $N$-hydroxysuccinimide (NHS) attached to the CPTA chelate (Fig. 2E) [7, 22]. In the case of BA, linkage is to sulfhydryl groups introduced into the protein by a first coupling reaction of lysine residues with iminothiolane (IT). In the case of NCS and NHS, coupling is directly to the primary amine groups of lysine residues. A triglycine linker between the DO3A chelator and the coupling group to the protein (Fig. 2D, F) was found to further improve the biodistribution of ${ }^{67} \mathrm{Cu}-\mathrm{DO} 3 \mathrm{~A}-$ and ${ }^{67} \mathrm{Cu}-\mathrm{CPTA}-$ labelled antibody fragments $[22,23]$. The extent of conjugation of chelates to the antibody has to be optimised in every case in order to ensure that immunoreactivity is retained after conjugation. It also has to be considered that even when no effect on immunoreactivity is observed, substituting the protein with too large a number of ligands can lead to significant changes in biodistribution and increased activity in the liver [24]. Ligand-substituted antibodies can be stored at $4{ }^{\circ} \mathrm{C}$ prior to labelling with ${ }^{67} \mathrm{Cu}$.

\section{${ }^{67} \mathrm{Cu}$ labelling}

Labelling with ${ }^{67} \mathrm{Cu}$ is performed by incubation of substituted antibodies with ${ }^{67} \mathrm{Cu}$ for $30 \mathrm{~min}$ at ambient temperature. Excess and non-specifically bound copper is complexed by addition of EDTA or an excess of the ligand used for labelling. Antibodies are then purified over a gel filtration column. These mild labelling conditions ensure that the immunoreactivity of the conjugates is fully retained. The specific activity of ${ }^{67} \mathrm{Cu}$-labelled immunoconjugates depends on the amount of chelates bound per antibody molecule, which is limited by damage to immunoreactivity and increases in normal tissue (mostly liver) uptake [24]. The specific activity of the ${ }^{67} \mathrm{Cu}$ used for labelling also represents a limiting factor. At present, specific activities of ${ }^{67} \mathrm{Cu}$-labelled immunoconjugates are in the range of $37 \mathrm{MBq}(1 \mathrm{mCi}) / \mathrm{mg}$. This is sufficiently high for in vivo antibody targetting, but currently many high-affinity receptor binding peptides cannot be labelled with ${ }^{67} \mathrm{Cu}$ to specific activities high enough for in vivo receptor binding. It is expected that higher labelling yields and higher specific activities will be achieved by increasing the ${ }^{67} \mathrm{Cu}$ production to $>50 \mathrm{GBq}$, because the amount of contamination by inactive copper present during the radiochemical isolation of ${ }^{67} \mathrm{Cu}$ from the irradiated target remains unchanged, resulting in an increased ratio of ${ }^{67} \mathrm{Cu}$ to $\mathrm{Cu}$. When ${ }^{67} \mathrm{Cu}$ with higher specific activity becomes accessible, it may also prove possible to label tumour targetting peptides to sufficiently high specific activities.

\section{Quality control of ${ }^{67} \mathrm{Cu}$-labelled antibodies}

Assessment of radiochemical purity and radionuclide identity

The fraction of radiocopper bound to antibody (radiochemical purity) can be determined by thin-layer chromatography (TLC) using silica gel and a solvent consisting of $10 \%$ ammonium acetate in $\mathrm{H}_{2} \mathrm{O}$ and methanol ( $\mathrm{vol} / \mathrm{vol}=1 / 1)$ [9]. Unchelated copper readily binds to protein and TLC solid phase; therefore EDTA solution is added to a final concentration of $5 \mathrm{~m} M$ to the antibody solution. After copper labelling and purification of labelled antibody by gel filtration FPLC chromatography, $>95 \%$ of the radiocopper is associated with antibody. 
Radionuclide identity can be assessed by gammaspectroscopy. We found that in antibody preparations labelled via the CPTA chelator, the amount of the main contaminants, ${ }^{67} \mathrm{Ga}\left(T_{1 / 2} 78.3 \mathrm{~h}\right)$ and ${ }^{57} \mathrm{Ni}\left(T_{1 / 2} 36 \mathrm{~h}\right)$, is below $5 \%$, and there is less than $0.1 \%{ }^{65} \mathrm{Zn}\left(T_{1 / 2} 244.3\right.$ days) in the ${ }^{67} \mathrm{Cu}$-labelled antibody preparations.

${ }^{64} \mathrm{Cu}$ is present in the ${ }^{67} \mathrm{Cu}$-labelled antibody preparation, the amount depending on the time that has elapsed since ${ }^{67} \mathrm{Cu}$ production (end of bombardment, EOB). An antibody preparation delivered $72 \mathrm{~h}$ after EOB with an activity of $37 \mathrm{MBq}$ of ${ }^{67} \mathrm{Cu}$ contains an additional $37 \mathrm{MBq}$ of ${ }^{64} \mathrm{Cu}$. Because of its shorter half-life, the activity due to ${ }^{64} \mathrm{Cu}$ declines more rapidly than that due to ${ }^{67} \mathrm{Cu}$. Because the photons emitted by ${ }^{64} \mathrm{Cu}$ contribute to the radiation burden of the patient and have an impact on image resolution, it is of interest to assess the amount that will be present at the time of application by measurement with a gamma-spectrometer or use of a calibrated ionisation chamber [25].

Assessment of antibody aggregates and of immunoreactivity

The purification of the ${ }^{67} \mathrm{Cu}$-labelled antibody by FPLC gel filtration chromatography assures optimal quality, because it not only separates the unchelated copper but also removes antibody aggregates which can lead to unwanted accumulation of radioactivity in the liver or spleen. Antibody aggregates are usually not generated by the labelling procedure, but are frequently present to a variable extent in the antibody solutions used for labelling. Immunoreactivity of the labelled preparation is tested by binding assays. If the antigen is not available in pure form, binding to antigen-expressing tumour cells (which can be fixed onto microtitre plates and stored in this form) is measured and evaluated according to the method reported by Lindmo et al. [26]. In the case of ${ }^{67} \mathrm{Cu}-\mathrm{C} 595$ anti-mucin antibody, where the epitope is known, binding to the peptide epitope attached to a solid phase support can be used [27].

\section{Biological behaviour of ${ }^{67} \mathrm{Cu}$-labelled antibodies}

\section{Comparison with ${ }^{131}$ I-labelled antibodies}

When a number of different ${ }^{67} \mathrm{Cu}$-labelled antibodies were assessed in nude mice bearing human tumour xenografts, it was found that they consistently showed higher tumour uptake and a longer residence time of radioactivity at the tumour than their radioiodinated counterparts $[19,20,28,29]$. Together with the low levels of radioactivity observed in normal tissues, the data indicated that ${ }^{67} \mathrm{Cu}$-labelled antibodies are superior tumour targetting vehicles. Accordingly, the antitumour activity of ${ }^{67} \mathrm{Cu}-$ labelled Lym-1 anti-lymphoma antibody in mice with human Burkitt's lymphoma was found to be higher than that of the corresponding ${ }^{131}$ I-labelled Lym-1 [30]. One of the reasons for these effects lies in the moderate stability of radioiodinated proteins towards enzymatic deiodination. In vivo the stability of radioiodinated antibodies, which are labelled on tyrosine residues, is affected by relatively rapid deiodination followed by fast elimination of iodotyrosine from tumour and normal tissues. The development of iodination methods providing deiodinase-resistant linkage of iodine to proteins has only partially overcome this problem [31, 32]. In the case of radiocopper-labelled antibodies, metabolism proceeds by digestion with proteases and peptidases and the terminal degradation product consists of lysine adducts of the copper complexes used for antibody labelling [20, 21]. Clearance of radioactivity from normal tissues such as the liver or the kidney depends on kinetic stability of the copper complexes and the charge and lipophilicity of the resulting metabolites. As already mentioned, despite the high kinetic stability of macrocyclic copper complexes, transchelation of $\mathrm{Cu}$ from the copper complex to copperbinding proteins in the liver has been observed in vivo with both ${ }^{67} \mathrm{Cu}$-TETA-labelled Lym-1 antibody [15] and ${ }^{64} \mathrm{Cu}$-TETA-labelled octreotide [16]. The antibody and the peptide conjugate are both metabolised in the liver. In the case of ${ }^{64} \mathrm{Cu}$-TETA-labelled octreotide, metabolism was studied in rat liver and $20 \mathrm{~h}$ post injection ${ }^{64} \mathrm{Cu}$ was found to be predominantly associated with a $32-\mathrm{kDa}$ protein co-migrating with the copper-binding liver enzyme superoxide dismutase [16]. When ${ }^{67} \mathrm{Cu}$-2IT-BATLym-1 antibody was administered to patients, a small fraction of ${ }^{67} \mathrm{Cu}$ (about $2.8 \%$ ) was found to be slowly recycled during metabolism and was detected bound to ceruloplasmin $[15,33]$.

In the case of internalising immunoconjugates, ${ }^{67} \mathrm{Cu}$ has a particular advantage over ${ }^{131} \mathrm{I}$. It has been shown that in the case of the anti-neuroblastoma antibody chCE7, which is taken up into target tumour cells and degraded in lysosomes [34], radioactivity from radioiodinated antibody is washed out from tumour cells, whereas the terminal metabolite of ${ }^{67} \mathrm{Cu}$-CPTA-chCE7 is retained intracellularly [35]. Consequently, ${ }^{67} \mathrm{Cu}$-labelled internalising immunoconjugates show a longer residence time in tumour, similar to that of conjugates with other "residualising" nuclides such as ${ }^{111}$ In and ${ }^{90} \mathrm{Y}[31,36$, 37], and should thus deliver higher tumour doses than ${ }^{131}$ I-labelled internalising antibodies.

\section{Comparison of intact antibody and antibody fragments}

The more rapid pharmacokinetics and better tumour penetration of antibody fragments are potentially valuable properties for applications in RAIT, and genetically engineered antibody single chain fragments $(\mathrm{scFv})$ as well as enzymatically prepared $\mathrm{Fab}^{\prime}$ and $\mathrm{F}\left(\mathrm{ab} \mathrm{b}^{\prime}\right)_{2}$ fragments labelled with various radionuclides have been evaluated 
Table 2. Biodistribution of ${ }^{67} \mathrm{Cu}$-labelled fragments of $\mathrm{mAb}$ chCE7 in nude mice bearing neuroblastoma xenografts. DOTA-R1 is the triglycine-linked chelate shown in Fig. 2D. (Data from Carrel et al. [38] and Zimmermann et al. [22])

\begin{tabular}{|c|c|c|c|c|}
\hline Tissue & $\begin{array}{l}{ }^{67} \mathrm{Cu}-\mathrm{CPTA}-\mathrm{chCE} 7 \\
\mathrm{Fab}^{\prime} \\
8 \text { h p.i. }\end{array}$ & $\begin{array}{l}{ }^{67} \mathrm{Cu}-\mathrm{CPTA}-\mathrm{chCE} 7 \\
\mathrm{~F}\left(\mathrm{ab}^{\prime}\right)_{2} \\
8 \mathrm{~h} \mathrm{p.i}\end{array}$ & $\begin{array}{l}{ }^{67} \mathrm{Cu}-\mathrm{DOTA}-\mathrm{R} 1-\mathrm{chCE} 7 \\
\mathrm{~F}\left(\mathrm{ab}^{\prime}\right)_{2} \\
8 \mathrm{~h} \mathrm{p.i}\end{array}$ & $\begin{array}{l}{ }^{67} \mathrm{Cu}-\mathrm{DOTA}-\mathrm{R} 1-\mathrm{chCE} 7 \\
\mathrm{~F}\left(\mathrm{ab}^{\prime}\right)_{2} \\
48 \mathrm{~h} \mathrm{p.i}\end{array}$ \\
\hline Tumour & $1.38 \pm 0.24$ & $9.03 \pm 1.7$ & $13.9 \pm 3.3$ & $16.6 \pm 2.6$ \\
\hline Blood & $0.46 \pm 0.12$ & $0.70 \pm 0.12$ & $12.9 \pm 1.0$ & $1.8 \pm 0.1$ \\
\hline Kidney & $138 \pm 41$ & $100.3 \pm 10$ & $15.9 \pm 1.3$ & $10.9 \pm 1.2$ \\
\hline Liver & $3.73 \pm 0.52$ & $6.4 \pm 2.8$ & $10.6 \pm 0.9$ & $10.1 \pm 0.4$ \\
\hline
\end{tabular}

for their tumour targetting ability. In the case of the internalising chCE7 antibody, the tumour targetting ability of ${ }^{67} \mathrm{Cu}$-labelled non-internalising monovalent $\mathrm{scFv}$ and Fab' fragments has been compared with internalising divalent $\mathrm{F}\left(\mathrm{ab}^{\prime}\right)_{2}$ fragments [38]. Table 2 summarises some of this work, indicating a ninefold increase in tumour uptake of ${ }^{67} \mathrm{Cu}$-CPTA-labelled $\mathrm{F}\left(\mathrm{ab}^{\prime}\right)_{2}$ fragments compared with ${ }^{67} \mathrm{Cu}-\mathrm{CPTA}-$ labelled $\mathrm{Fab}^{\prime}$ fragments. Compared with the moderate tumour uptake achieved with monovalent Fab' fragments, divalent internalising antibody fragments combine high tumour uptake with rapid clearance from the blood and therefore could potentially attain a better therapeutic index than intact antibodies. However, as indicated in Table 2, high levels of radioactivity in the kidneys are observed with ${ }^{67} \mathrm{Cu}$-CPTA-labelled $\mathrm{Fab}^{\prime}$ and $\mathrm{F}\left(\mathrm{ab}^{\prime}\right)_{2}$ antibody fragments, proteins which are metabolised in the kidney, and the metabolite ${ }^{67} \mathrm{Cu}$-CPTA-Lys is retained in the proximal tubule cells [20]. Similarly, high retention of radioactivity in the kidneys was found with a number of other antibody fragments, labelled with ${ }^{67} \mathrm{Cu}$ [28] and with the PET nuclide ${ }^{64} \mathrm{Cu}$ [39]. Blockade of renal uptake with lysine was found to reduce radioactivity in the kidneys in the case of ${ }^{67} \mathrm{Cu}$-CPTA-labelled SEN7$\mathrm{F}\left(\mathrm{ab} \mathrm{b}_{2}\right.$ fragments, but was not effective in reducing kidney accumulation of radioactivity from ${ }^{67} \mathrm{Cu}-\mathrm{CPTA}-$ $\mathrm{mAb} 35 \mathrm{~F}\left(\mathrm{ab}^{\prime}\right)_{2}$, indicating that it is not a generally applicable solution to reduce radioactivity in the kidneys [40]. Another approach to reduce radioactivity in the kidney is to use chelates bearing negative charges and to introduce cleavable linkers between antibody fragments and $\mathrm{Cu}$ chelates. We found that a triglycine linker (originally introduced by Li and Meares [14]) improved clearance of ${ }^{67} \mathrm{Cu}-\mathrm{CPTA}-\mathrm{F}\left(\mathrm{ab}^{\prime}\right)_{2}$ from the kidney, possibly by leading to a metabolite with a terminal Gly instead of a terminal Lys residue, which is not taken up into proximal tubule cells [22]. Data in Table 2 show that when the triglycine linker was combined with the anionic DO3A chelate, the $\mathrm{F}(\mathrm{ab})_{2}$ conjugate with the triglycine linkage group showed about a sixfold reduction in radioactivity present in the kidneys owing to the negative charge of the DO3A chelate and, at the same time, significantly higher tumour uptake, probably due to its slower pharmacokinetics $[22,23]$. Substantial improvement in the biodistribution of ${ }^{67} \mathrm{Cu}$-labelled $\mathrm{F}\left(\mathrm{ab}^{\prime}\right)_{2}$ fragments can thus be
Table 3. Cumulative retention of radioactivity (AUC) in tumour and tissues of neuroblastoma-bearing nude mice: comparison of ${ }^{67} \mathrm{Cu}$-DOTA-R1-chCE7 $\mathrm{F}\left(\mathrm{ab}^{\prime}\right)_{2}$ fragments with intact ${ }^{67} \mathrm{Cu}-\mathrm{CPTA}$ chCE7 antibody. (From Zimmermann et al. [22])

\begin{tabular}{|c|c|c|c|c|}
\hline \multirow[t]{2}{*}{ Tissue } & \multicolumn{2}{|c|}{$\begin{array}{l}{ }^{67} \mathrm{Cu}-\mathrm{DOTA}-\mathrm{R} 1-\mathrm{chCE} 7 \\
\mathrm{~F}\left(\mathrm{ab}^{\prime}\right)_{2}\end{array}$} & \multicolumn{2}{|c|}{${ }^{67} \mathrm{Cu}-\mathrm{CPTA}-\mathrm{chCE} 7$} \\
\hline & AUC & AUC ratio & AUC & AUC ratio \\
\hline Tumour & 1,716 & - & 5,460 & - \\
\hline Blood & 466 & 3.7 & 599 & 9.1 \\
\hline Kidney & 1,478 & 1.2 & 1,783 & 3.1 \\
\hline Liver & 1,408 & 1.2 & 950 & 5.7 \\
\hline
\end{tabular}

achieved by chemical modification of copper chelates. However, when the therapeutic efficacy of intact ${ }^{67} \mathrm{Cu}$-labelled chCE7 antibody was compared with that of the ${ }^{67} \mathrm{Cu}-\mathrm{DOTA}-\mathrm{R} 1-\mathrm{F}(\mathrm{ab})_{2}$ fragment by calculating the accumulated dose (AUC) in tumour and normal tissues from an extended time course of biodistributions, the intact antibody still achieved better therapeutic ratios than the $\mathrm{F}(\mathrm{ab})_{2}$ fragment (Table 3). The data indicate that intact ${ }^{67} \mathrm{Cu}$-labelled antibodies maximise tumour uptake and therefore achieve better therapeutic ratios and that they are at present the logical choice for clinical studies.

\section{Comparison with ${ }^{64} \mathrm{Cu}$-labelled antibodies}

In contrast to the ${ }^{67} \mathrm{Cu}$ nuclide, ${ }^{64} \mathrm{Cu}$, a PET nuclide, can be produced with high specific activity, for instance by irradiation of ${ }^{64} \mathrm{Ni}$ targets with low-energy proton currents [41]. In addition to its emissions of $\beta^{+}$radiation used for imaging, ${ }^{64} \mathrm{Cu}$ also emits therapeutic $\beta^{-}$particles. Its physical characteristics of quite different from those of ${ }^{67} \mathrm{Cu}$, and include higher (therapeutically useless) $\gamma$ energies and a shorter half-life $(12.7 \mathrm{~h})$ (see Table 1). In addition to their application in PET imaging, ${ }^{64} \mathrm{Cu}$-labelled antibodies and peptides show therapeutic effects in animal tumour models [42, 43] and they could be potential agents for nuclide therapy. Although no clinical data relating to the administration of therapeutic 
amounts of ${ }^{64} \mathrm{Cu}$-labelled radiopharmaceuticals have appeared so far, in the case of radiocopper-labelled intact antibodies $\left({ }^{67 / 64} \mathrm{Cu}\right.$-2IT-BAT-Lym1), quantitative imaging and estimates of radiation dosimetry indicate that the ${ }^{67} \mathrm{Cu}$-labelled antibody has a therapeutic advantage over the ${ }^{64} \mathrm{Cu}$-labelled antibody in patients [44]. This is due to the more favourable energy deposition of the ${ }^{67} \mathrm{Cu}$ nuclide, with its smaller contribution from penetrating $\gamma$-radiation, and to the longer half-life of ${ }^{67} \mathrm{Cu}$, which is more compatible with the relatively slow pharmacokinetics of antibodies. In the case of receptor binding peptides with rapid pharmacokinetics, such as octreotide, which has been evaluated as ${ }^{64} \mathrm{Cu}$-TETA-octreotide for imaging of neuroendocrine tumours [45], the situation may be different, and a direct comparison of ${ }^{67} \mathrm{Cu}$ with the ${ }^{64} \mathrm{Cu}$ nuclide concerning both imaging/dosimetry and therapeutic efficacy would be of particular interest.

\section{Clinical studies with ${ }^{67} \mathrm{Cu}$-labelled antibodies}

\section{Targetting of non-Hodgkin's lymphoma with ${ }^{67} \mathrm{Cu}$-2IT-BAT-Lym-1}

Clinical studies with ${ }^{67} \mathrm{Cu}$-labelled antibodies were pioneered by the groups of S.J. and G.L. DeNardo at the University of California Davis Medical Center [33, 46, $47,48]$. Their clinical target was non-Hodgkin's lymphoma (NHL). They were able to show that RAIT with ${ }^{131} \mathrm{I}-$ labelled anti-lymphoma Lym-1 antibody is successful in inducing therapeutic responses and prolonged survival [49]. In order to evaluate ${ }^{67} \mathrm{Cu}$, with its better physical characteristics, as a replacement for ${ }^{131} \mathrm{I}$, a ${ }^{67} \mathrm{Cu}$-TETAlabelled Lym-1 radiopharmaceutical ${ }^{67} \mathrm{Cu}$-2IT-BATLym-1) was developed. Labelling protocols were optimised for specific activity to reduce the amount of antibody per dose [24]. When immunological responses were monitored after repeated administrations of therapeutic amounts of the ${ }^{67} \mathrm{Cu}-\mathrm{mAb}$ (40-70 mg of Lym-1 antibody with 125-267 $\mu \mathrm{g}$ of TETA conjugated to the antibody), HAMA were detected in some instances (Lym-1 is a mouse monoclonal antibody) but no antibodies against the TETA chelating moiety were found [50]. The results indicated that human antibody responses are not limiting for the repeated applications necessary in fractionated therapy. In a pilot study in three patients with advanced B-lymphocyte NHL, an imaging dose of $370 \mathrm{MBq}$ $(10 \mathrm{mCi})$ of ${ }^{67} \mathrm{Cu}-2$ IT-BAT-Lym-1 was applied, followed by a maximum of four therapy doses of $2.2 \mathrm{GBq}$ $(60 \mathrm{mCi})$ of the ${ }^{67} \mathrm{Cu}$-antibody at intervals of 4 weeks [33]. Good tumour imaging, favourable radiation dosimetry and a high therapeutic index (tumour to bone marrow radiation doses) were found. The maximum tolerated dose (MTD) for each of the first two doses was $2.2 \mathrm{GBq} / \mathrm{m}^{2}$, haematological toxicity being the dose-limiting factor. In a subsequent clinical trial with $12 \mathrm{NHL}$ patients, a response rate of 58\% was found [48]. Sequen- tial application of ${ }^{131} \mathrm{I}-\mathrm{Lym}-1$ and ${ }^{67} \mathrm{Cu}$-2IT-BAT-Lym-1 was performed in four patients to evaluate ${ }^{131} \mathrm{I}-$ and ${ }^{67} \mathrm{Cu}$-antibody in terms of their pharmacokinetics and dosimetry, and it was found that ${ }^{67} \mathrm{Cu}$-2IT-BAT-Lym-1 showed higher tumour uptake and a longer residence time in the tumour than ${ }^{131} \mathrm{I}-\mathrm{Lym}-1$. Doses to normal organs were similar for the two radiopharmaceuticals, with the exception of the liver, where ${ }^{67} \mathrm{Cu}$-2IT-BAT-Lym-1 led to a higher dose [47]. The results obtained so far indicate that ${ }^{67} \mathrm{Cu}$-2IT-BAT-Lym-1 is a safe and effective reagent for RAIT and delivers higher doses to tumour than ${ }^{131} \mathrm{I}-\mathrm{Ly}-\mathrm{m}-1$. It is clear that a larger number of patients will have to be treated in order to confirm that, compared with ${ }^{131} \mathrm{I}$-Lym-1, ${ }^{67} \mathrm{Cu}$-2IT-BAT-Lym-1 yields better therapeutic responses or cure.

\section{Targetting of colon carcinoma with ${ }^{67} \mathrm{Cu}-\mathrm{CPTA}-\mathrm{mAb} 35$}

In patients with colorectal tumours, RAIT is believed to be a valuable option in the presence of limited disease and/or in an adjuvant setting with chemotherapy [51].

A study in six patients was performed at the University Hospital in Lausanne, Switzerland, comparing the biodistribution of ${ }^{67} \mathrm{Cu}-\mathrm{CPTA}-$ and ${ }^{125}$ I-labelled anti-CEA antibody mAb35 [52]. Patients were scheduled for surgery of primary colorectal cancer. Prior to surgery $185 \mathrm{MBq}(5 \mathrm{mCi})$ of ${ }^{67} \mathrm{Cu}-\mathrm{CPTA}-\mathrm{mAb} 35$ was co-injected together with $8.9 \mathrm{MBq}(0.24 \mathrm{mCi})$ of ${ }^{125} \mathrm{I}-\mathrm{mAb} 35$. Whole-body scanning and single-photon emission tomography were performed $1 \mathrm{~h}, 1$ day and 2 days after injection. Surgery was performed 2-8 days post injection, and radioactivity in samples of tumour, normal colonic mucosa, fat and blood was measured. The study confirmed preclinical data in nude mice bearing human colon carcinoma xenografts, which showed higher tumour uptake and more favourable tumour to blood ratio with ${ }^{67} \mathrm{Cu}-\mathrm{mAb} 35$ compared with ${ }^{131} 1-\mathrm{mAb} 35$ [28]. However, liver uptake was noticeably higher in patients than in the animal model. It was concluded that the possibilities of achieving tumour response or cure are severely limited in solid tumours, such as colon carcinoma, regardless of whether ${ }^{131} \mathrm{I}$ - or ${ }^{67} \mathrm{Cu}$-labelled antibodies are used. This is also supported by observations in various clinical RAIT trials of solid tumours, where the low radiation doses delivered by RAIT are less effective than in the case of lymphomas, which show therapeutic responses even at low tumour doses.

\section{Targetting of bladder cancer with ${ }^{67} \mathrm{Cu}-\mathrm{CPTA}-\mathrm{C} 595$}

The best results in RAIT of solid tumours have been obtained through locoregional administration of radiolabelled antibodies after reduction of the tumour burden by surgery and radiation. Response rates of more than $50 \%$ and prolonged survival have been achieved following in- 

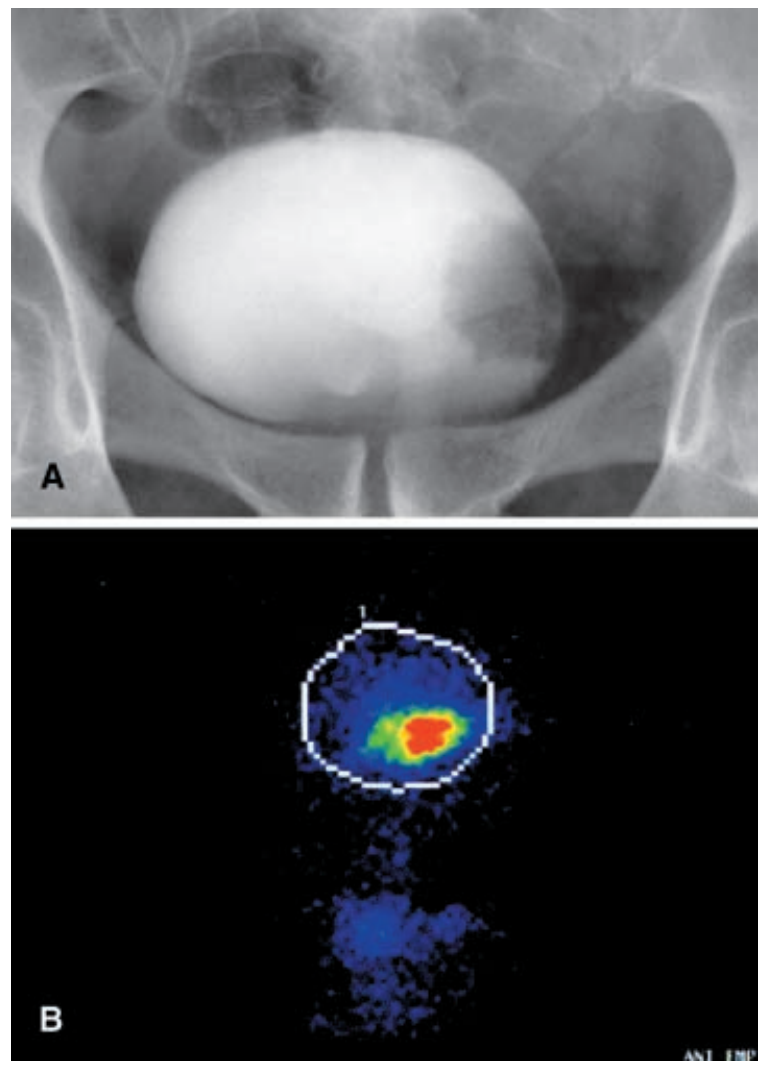

Fig. 3. A Intravenous urography and $\mathbf{B}$ gamma camera image from a patient with left-sided bladder tumour and corresponding area of activity after washout of ${ }^{67} \mathrm{Cu}-\mathrm{CPTA}-\mathrm{C} 595$ antibody. (From Hughes et al. [57])

tralesional application of ${ }^{131} \mathrm{I}-$ or ${ }^{90} \mathrm{Y}-$ labelled anti-tenascin antibodies in malignant glioma [53] and intraperitoneal application of ${ }^{90} \mathrm{Y}$ - or ${ }^{177} \mathrm{Lu}$-labelled antibodies against ovarian cancer $[54,55]$.

In the case of superficial bladder cancer, more effective locoregional therapies are being sought in order to limit recurrence and progression. The majority of bladder cancer patients suffer from superficial disease confined to the mucosa, and after endoscopic resection there is a high incidence of recurrent disease. Treatment by intravesical chemotherapy has so far shown limited efficacy and significant side-effects. Intravesical application of radiolabelled tumour-specific monoclonal antibodies may be a more effective modality, targetting cytotoxic radiation selectively to tumour tissue. The C595 monoclonal antibody recognises a peptide epitope in the MUC1 mucin, a glycoprotein which is up-regulated on malignant bladder urothelium. Localisation of bladder tumour after intravesical application of ${ }^{111}$ In-labelled C595 was demonstrated in the mid 1990s [56]. Subsequently, pilot studies were performed on cystectomy patients, in which bladders were infused ex vivo with ${ }^{67} \mathrm{Cu}-\mathrm{CPTA}-\mathrm{C} 595$ via a catheter immediately after surgery. After incubation for $1 \mathrm{~h}$, unbound antibody was washed out and the bladder was imaged with a gamma camera. Ex vivo imaging demonstrated antibody localisation corresponding to the sites of the tumour as confirmed histologically [27]. A diagnostic study with 16 patients diagnosed with superficial bladder cancer followed [57]. ${ }^{67} \mathrm{Cu}-\mathrm{CPTA}-\mathrm{C} 595$ (approximately $20 \mathrm{MBq}$ ) was instilled in the bladder and after $1 \mathrm{~h}$ the bladder was drained and irrigated. Both imaging and tissue counting of tumour and normal tissues obtained by endoscopic resection was performed and showed successful imaging in 12 out of 15 patients; an example is shown in Fig. 3. A mean tumour to normal tissue ratio of 15:1 was found, with large variations among patients (there is high variation in MUC1 expression in different tumours). When serum levels of radioactivity were analysed after instillation of ${ }^{67} \mathrm{Cu}-\mathrm{C} 595$ into the bladder, no increase was found, indicating that the activity remains enclosed in the bladder. These results obtained by the groups at the City Hospital and at the University Hospital in Nottingham (UK) indicate that ${ }^{67} \mathrm{Cu}-\mathrm{C} 595$ holds significant potential for local therapy of bladder cancer, and a phase $\mathrm{I} / \mathrm{II}$ trial with doses up to $1.0 \mathrm{GBq}$ is underway.

\section{Conclusions and prospects}

Based on the good results of preclinical and clinical evaluations of ${ }^{67} \mathrm{Cu}$-labelled antibodies, broader clinical investigations in radioimmunotherapy trials are desirable. The availability of the ${ }^{67} \mathrm{Cu}$ nuclide is a limiting factor for its more widespread use. Efforts to develop efficient procedures to produce large amounts of ${ }^{67} \mathrm{Cu}$ with high specific activity would significantly help the cause of this interesting nuclide.

\section{References}

1. O’Donoghue JA, Bardies M, Wheldon TE. Relationships between tumor size and curability for uniformly targeted therapy with beta-emitting radionuclides. J Nucl Med 1995; 36:19021909.

2. Schubiger PA, Smith AM. Vehicles, chelators and radionuclides: choosing the "building blocks" of an effective therapeutic radioimmunoconjugate. Bioconjugate Chem 1996; 7:165179 .

3. Mausner LF, Kolsky KL, Joshi V, Srivastava SC. Radionuclide development at BNL for nuclear medicine therapy. Appl Radiat Isot 1998; 49:285-294.

4. Schwarzbach R, Zimmermann K, Blaeuenstein P, Smith A, Schubiger PA. Development of a simple and selective separation of $67-\mathrm{Cu}$ from irradiated zinc for use in antibody labelling: a comparison of methods. Appl Radiat Isot 1995; 46: 329-336.

5. Dasgupta AK, Mausner LF, Srivastava SC. A new separation procedure for $\mathrm{Cu}-67$ from proton irradiated $\mathrm{Zn}$. J Appl Radiat Isot 1991; 42:371-376.

6. Schwarzbach R, Zimmermann K, Novak-Hofer I, Schubiger PA. A comparison of $67-\mathrm{Cu}$ production by proton (67 to $12 \mathrm{MeV}$ ) induced reactions on nat- $\mathrm{Zn}$ and on enriched 68- 
Zn/70-Zn. J Labelled Compd Radiopharm 2001; 44 Suppl $1: 809-811$.

7. Meares CF, Mc Call MJ, Reardan DT, Goodwin DA, Diamanti CI, McTigue M. Conjugation of antibodies with bifunctional chelating agents: isothiocyanate and bromoacetamide reagents, methods of analysis and subsequent addition of metal ions. Anal Biochem 1984; 142:68-78.

8. Moi MK, Meares CF, Mc Call MJ, Cole WC, DeNardo SJ. Copper chelates as probes of biological systems: stable copper complexes with a macrocyclic bifunctional chelating agent. Anal Biochem 1985; 148:249-253.

9. Kukis DL, Li M, Meares CF. Selectivity of antibody-chelate conjugates for binding copper in the presence of competing metals. Inorg Chem 1993; 32:3981.

10. Kukis DL, Diril H, Greiner DP, DeNardo GL, Salako QA, Meares CF. A comparative study of copper-67 radiolabeling and kinetic stabilities of antibody-macrocycle chelate conjugates. Cancer 1993; 73 Suppl:779-786.

11. Morphy JR, Parker D, Kataky R, Eaton MAW, Millican AT, Alexander R, Harrison A, Walker C. Towards tumour targeting with copper-radiolabelled macrocycle-antibody conjugates: synthesis, antibody linkage, and complexation behaviour. $J$ Chem Soc Perkin Trans 1990; 2:573-584.

12. Ruser G, Ritter W, Maecke HR. Synthesis and evaluation of two new bifunctional carboxymethylated tetraazamacrocyclic chelating agents for protein labeling with indium-111. Bioconjugate Chem 1990; 2:345-349.

13. Studer M, Kaden TA, Maecke HR. Metal complexes with macrocyclic ligands: reactivity studies of the pendant carboxylic group in a macrocyclic $\mathrm{Cu}^{2+}$ complex towards amide formation and its use as a protein labeling agent. Helv Chim Acta 1990; 73:149-153.

14. Li M, Meares CF. Synthesis, metal chelate stability studies and enzyme digestion of a peptide-linked DOTA derivative and its corresponding radiolabeled immunoconjugates. Bioconjugate Chem 1993; 4:275-283.

15. Mirick GR, O'Donnell RT, DeNardo SJ, Shen S, Meares CF, DeNardo GL. Transfer of copper from a chelated 67-Cu-antibody conjugate to ceruloplasmin in lymphoma patients. $\mathrm{Nucl}$ Med Biol 1999; 26:841-845.

16. Bass LA, Wang M, Welch MJ, Anderson CJ. In vivo transchelation of copper-64 from TETA-octreotide to superoxide dismutase in rat liver. Bioconjugate Chem 2000; 11:527-532.

17. Boswell CA, Sun X, Wang M, Ramos B, Weisman GR, Wong $\mathrm{EH}$, Anderson CJ. Relationship between reduction potential and in vivo stability of copper-azamacrocycle complexes. $J$ Labelled Compd Radiopharm 2001; 44 Suppl 1:5770-5772.

18. Sun X, Anderson CJ, Wuest M, Welch MJ, Peng Y, Weisman GR, Wong EH. Copper-64 radiolabeling and in vivo behavior of 4,11-bis(carboxymethyl)-1,4,8,11-tetraazabicyclo[6.6.2]hexadecane. J Labelled Compd Radiopharm 2001; 44 Suppl 1: $5784-5786$

19. Smith-Jones PM, Fridrich R, Kaden TA, Novak-Hofer I, Siebold K, Tschudin D, Maecke HR. Antibody labeling with copper-67 using the bifunctional macrocycle 4-[(1,4,8,11-tetraazacyclotetradec-1-yl)methyl]benzoic acid. Bioconjugate Chem 1991; 2:415-421.

20. Novak-Hofer I, Zimmermann K, Maecke HR, Amstutz H, Carrel F, Schubiger PA. Tumor uptake and metabolism of copper-67-labeled monoclonal antibody chCE7 in nude mice bearing neuroblastoma xenografts. J Nucl Med 1997; 38:536-544.

21. Rogers BE, Anderson CJ, Connett JM, Guo LW, Edwards WB, Sherman ELC, Zinn KR, Welch MJ. Comparison of four bi- functional chelates for radiolabeling monoclonal antibodies with copper radioisotopes: biodistribution and metabolism. Bioconjugate Chem 1996; 7:511-522.

22. Zimmermann K, Gianollini S, Schubiger PA, Novak-Hofer I. A triglycine linker improves tumor uptake and biodistributions of 67-Cu-labeled anti-neuroblastoma mAb chCE7 F(ab') $)_{2}$ fragments. Nucl Med Biol 1999; 26:943-950.

23. Novak-Hofer I, Zimmermann K, Schubiger PA. Peptide linkers lead to modification of liver metabolism and improved tumor targeting of 67-Cu-labeled antibody fragments. Cancer Biother Radiopharm 2001; 16:469-481.

24. Kukis DL, DeNardo GL, DeNardo SJ, Mirick GR, Miers LA, Greiner DP, Meares CF. Effect of the extent of chelate substitution on the immunoreactivity and biodistribution of 2ITBAT-Lym-1 immunoconjugates. Cancer Res 1995; 55:878884.

25. DeNardo GL, Kukis DL, Shen S, DeNardo SJ. Accurate measurement of copper-67 in the presence of copper-64 contaminant using a dose calibrator. J Nucl Med 1996; 37:302-306.

26. Lindmo T, Boven E, Cuttitta F, Fedorko J, Bunn PA. Determination of the immunoreactive fraction of monoclonal antibodies by linear extrapolation to binding at infinite antigen excess. J Immunol Methods 1984; 72:77-89.

27. Hughes OD, Bishop MC, Perkins AC, Frier M, Price MR, Denton G, Smith A, Rutherford R, Schubiger PA. Preclinical evaluation of copper-67 labelled anti-MUC1 mucin antibody C595 for therapeutic use in bladder cancer. Eur J Nucl Med 1997; 24:439-443.

28. Smith A, Alberto R, Blaeuenstein P, Novak-Hofer I, Maecke $\mathrm{HR}$, Schubiger PA. Preclinical evaluation of 67-Cu-labeled intact and fragmented anti-colon carcinoma monoclonal antibody mAb35. Cancer Res 1993; 53:5727-5733.

29. Deshpande SV, DeNardo SJ, Kukis D, Diril H, Suey C, Meares CF. Copper-67 labeled monoclonal antibody Lym-1, a potential radiopharmaceutical for cancer therapy: labeling and biodistribution in RAJI-tumored mice. J Nucl Med 1988; 29:217-225

30. DeNardo GL, Kukis DL, Sui S, Mausner LF, Meares CF, Srivastava SC, Miers LA, DeNardo SJ. Efficacy and toxicity of 67-Cu-2IT-BAT-Lym-1 radioimmunoconjugate in mice implanted with human Burkitt's lymphoma (Raji). Clin Cancer Res 1997; 3:71-79.

31. Reist CJ, Archer GE, Wikstrand CJ, Bigner D, Zalutsky MR Improved targeting of anti-epidermal growth factor receptor variant III monoclonal antibody in tumor xenografts after labeling using $N$-succinimidyl 5-iodo-3-pyridinecarboxylate. Cancer Res 1997; 57:1510-1515.

32. Govindan SV, Mattes MJ, Stein R, McBride BJ, Karacay H, Goldenberg DM, Hansen HJ, Griffiths GL. Labeling of monoclonal antibodies with diethylenetriaminepentaacetic acidappended radioiodinated peptides containing D-amino acids. Bioconjugate Chem 1999; 10:231-240.

33. DeNardo GL, DeNardo SJ, Kukis DL, O'Donnell RT, Shen S, Goldstein DS, Kroger LA, Salako Q, DeNardo DA, Mirick GR, Mausner LF, Srivastava SC, Meares CF. Maximum tolerated dose of 67-Cu-2IT-BAT-LYM-1 for fractionated radioimmunotherapy of non-Hodgkin's lymphoma: a pilot study. Anticancer Res 1998; 18:2779-2788.

34. Novak-Hofer I, Amstutz H, Morgenthaler JJ, Schubiger PA. Internalization and degradation of monoclonal antibody chCE7 by human neuroblastoma cells. Int J Cancer 1994; 57:427-432.

35. Novak-Hofer I, Amstutz HP, Maecke HR, Schwarzbach R, Zimmermann K, Morgenthaler JJ, Schubiger PA. Cellular pro- 
cessing of copper-67-labeled monoclonal antibody chCE7 by human neuroblastoma cells. Cancer Res 1995; 55:46-50.

36. Sharkey RM, Behr TM, Mattes MJ, Stein R, Griffiths GL, Shih LB, Hansen HJ, Blumenthal RD, Dunn RM, Juweid ME, Goldenberg DM. Advantage of residualizing radiolabels for an internalizing antibody against B-cell lymphoma antigen, CD22. Cancer Immunol Immunother 1997; 44:179-188.

37. Press OW, Shan D, Howell-Clark J, Eary J, Appelbaum FR, Matthews D, King DJ, Haines AM, Hamann P, Hinman L, Shochat D, Bernstein ID. Comparative metabolism and retention of iodine-125, yttrium-90, and indium-111 radioimmunocinjugates by cancer cells. Cancer Res 1996; 56:2123-2129.

38. Carrel F, Amstutz H, Novak-Hofer I, Schubiger PA. Evaluation of radioiodinated and radiocopper labeled monovalent fragments of monoclonal antibody chCE7 for targeting of neuroblastoma. Nucl Med Biol 1997; 24:539-546.

39. Anderson CJ, Schwarz SW, Connett JM, Cutler PD, Guo LW, Germain CJ, Philpott GW, Zinn KR, Greiner DP, Meares CF, Welch MJ. Preparation, biodistribution and dosimetry of copper-64-labeled anti-colorectal carcinoma monoclonal antibody fragments $1 \mathrm{~A} 3 \mathrm{~F}\left(\mathrm{ab}^{\prime}\right)_{2}$. J Nucl Med 1995; 36:850-858.

40. Rutherford RAD, Smith A, Waibel R, Schubiger PA. Differential inhibitory effect of L-lysine on renal accumulation of 67Cu-labelled $\mathrm{F}\left(\mathrm{ab}^{\prime}\right)_{2}$ fragments in mice. Int J Cancer 1997; 72:522-529.

41. McCarthy DW, Shefer RE, Klinkowstein RE, Bass LA, Margeneau WH, Cutler CS, Anderson CJ, Welch MJ. Efficient production of high specific activity $64-\mathrm{Cu}$ using a biomedical cyclotron. Nucl Med Biol 1997; 24:35-43.

42. Connett JM, Anderson CJ, Guo LW, Schwarz SW, Zinn KR, Rogers BE, Siegel BA, Philpott GW, Welch MJ. Radioimmunotherapy with a 64-Cu-labeled monoclonal antibody: a comparison with 67-Cu. Proc Natl Acad Sci USA 1996; 93:68146818.

43. Anderson CJ, Jones LA, Bass LA, Sherman EL, McCarthy DW, Cutler PD, Lanahan MV, Cristel ME, Lewis JS, Schwarz SW. Radiotherapy, toxicity and dosimetry of copper-64TETA-octreotide in tumor-bearing rats. J Nucl Med 1998; 39:1944-1951.

44. Shen S, DeNardo GL, DeNardo SJ, Salako Q, Morris G, Banks D, Yuan A, DeNardo DA. Dosimetric evaluation of copper-64 in copper-67-2IT-BAT-Lym-1 for radioimmunotherapy. J Nucl Med 1996; 37:146-150.

45. Anderson CJ, Dehdashti, F, Cutler PD, Schwarz SW, Laforest R, Bass LA, Lewis JS, McCarthy DW. 64-Cu-TETA-octreotide as a PET imaging agent for patients with neuroendocrine tumors. J Nucl Med 2001; 42:213-221.

46. DeNardo GL, DeNardo SJ, Meares CF, Kukis DL, Diril H, McCall MJ, Adams GD, Mausner LF, Moody DC, Deshpande SV. Pharmacokinetics of copper-67 conjugated Lym-1, a potential therapeutic radioimmunoconjugate, in mice and pa- tients with lymphoma. Antibody Immunoconj Radiopharm 1991; 4:777-785.

47. DeNardo GL, Kukis DL, Shen S, DeNardo DA, Meares CF, DeNardo SJ. 67-Cu versus 131-I-labeled Lym-1 antibody: comparative pharmacokinetics and dosimetry in patients with non-Hodgkin's lymphoma. Clin Cancer Res 1999; 5:533-541.

48. O'Donnell RT, DeNardo GL, Kukis DL, Lamborn KR, Shen S, Yuan A, Goldstein DS, Carr CE, Mirick GR, DeNardo SJ. A clinical trial of radioimmunotherapy with 67-Cu-2IT-BATLym-1. J Nucl Med 1999; 40:2014-2020.

49. DeNardo GL, Lamborn KL, Goldstein DS, Kroger LA, DeNardo SJ. Increased survival associated with radiolabeled Lym-1 therapy for non-Hodgkin's lymphoma (NHL) and chronic lymphocytic leukemia (CLL). Cancer Suppl 1997; 80:2706-2711.

50. DeNardo GL, Mirick GR, Kroger LA, O’Donnell RT, Meares CF, DeNardo SJ. Antibody responses to macrocycles in lymphoma. J Nucl Med 1996; 37:451-456.

51. Behr TM, Sharkey RM, Juweid ME, Dunn RM, Ying Z, Zhang $\mathrm{CH}$, Siegel JA, Goldenberg DM. Variables influencing tumor dosimetry in radioimmunotherapy of CEA-expressing cancers with anti-CEA and antimucin monoclonal antibodies. $\mathrm{J} \mathrm{Nucl}$ Med 1997; 38:409-418.

52. Delaloye AB, Delaloye B, Buchegger F, Vogel CA, Gillet M, Mach JP, Smith A, Schubiger PA. Comparison of copper-67and iodine-125-labeled anti-CEA monoclonal antibody biodistribution in patients with colorectal tumors. J Nucl Med 1997; 38:847-853.

53. Riva P, Franceschi G, Riva N, Casi M, Santimaria M, Adamo M. Role of nuclear medicine in the treatment of malignant gliomas: the locoregional radioimmunotherapy approach. Eur J Nucl Med 2000; 27:601-609.

54. Alvarez RD, Partridge EE, Khazaeli MB, Plott G, Austin M, Kilgore L, Russell CD, Liu T, Grizzle WE, Schlom J, LoBuglio AF, Meredith RF. Intraperitoneal radioimmunotherapy of ovarian cancer with ${ }^{177} \mathrm{Lu}-\mathrm{CC} 49$ : a phase I/II study. Gynecol Oncol 1997; 65:94-101.

55. Nicholson S, Gooden CS, Hird V, Maraveyas A, Mason P, Lambert HE, Meares CF, Epenetos AA. Radioimmunotherapy after chemotherapy compared to chemotherapy alone in the treatment of advanced ovarian cancer: a matched analysis. Oncol Reports 1998; 5:223-226.

56. Kunkler RB, Bishop MC, Green DJ, Pimm MV, Price MR, Frier M. Targeting of bladder cancer with monoclonal antibody NCRC48 - a possible approach for intravesical therapy. Br J Urol 1995; 76:81-86.

57. Hughes ODM, Bishop MC, Perkins AC, Wastie ML, Denton G, Price MR, Frier M, Denley H, Rutherford R, Schubiger PA. Targeting superficial bladder cancer by the intravesical administration of copper-67-labeled anti-MUC1 mucin monoclonal antibody C595. J Clin Oncol 2000; 18:363-370. 